\title{
A high-fat diet as a model of fatty liver disease in rats ${ }^{1}$
}

\author{
Dieta hiperlipídica como modelo de esteatose hepática em ratos
}

\author{
Monike Garlipp Picchi', Andresa Marques de Mattos ${ }^{\mathrm{I}}$, Marina Rodrigues Barbosa ${ }^{\mathrm{II}}$, Camila Passos Duarte ${ }^{\mathrm{III}}$, Maria de

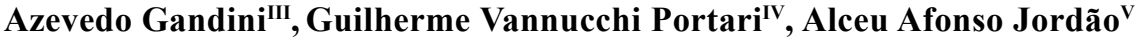 \\ ${ }^{I}$ Master, Nutricionist, Department of Internal Medicine, FMRP-USP, Ribeirao Preto-SP, Brazil. Acquisition, interpretation of data, critical revision \\ and manuscript writing. \\ ${ }^{I I}$ Fellow Master degree, Nutricionist, Department de Biochemistry and Immunology, FMRP-USP, Ribeirao Preto-SP, Brazil. Acquisition and \\ interpretation of data.

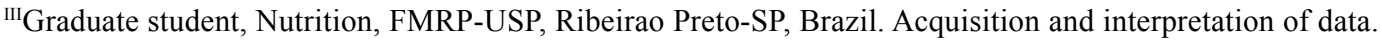 \\ ${ }^{\mathrm{IV}} \mathrm{PhD}$, Professor of Experimental Nutrition, Federal University of Triangulo Mineiro (UFTM), Uberaba-MG, Brazil. Acquisition and interpretation \\ of data. \\ ${ }^{v} \mathrm{PhD}$, Professor of Experimental Nutrition, FMRP-USP, Ribeirao Preto-SP, Brazil. Conception, design, responsible for intellectual and scientific \\ content of the study.
}

\begin{abstract}
PURPOSE: The objective of the present study was to analyze the physiological and metabolic changes occurring in rats subjected to high-fat diet for one month.

METHODS: The animals received a modified AIN-93 diet with increased lipid content and decreased carbohydrate content, while the control group received the normal AIN-93 diet.

RESULTS: It was observed that the high-fat diet did not induce weight gain but led to greater gain of hepatic fat compared to control. Biochemcal parameters, glycemia, total cholesterol and serum protein did not differ between groups. In parallel, rats receiving the high-fat diet consumed less feed.

CONCLUSION: The development of obesity through high-fat diet is associated with increased energy intake and time of exposure to the diet, while the metabolic syndrome is more associated with the combination of a diet rich in fat and carbohydrates.

Key words: Obesity. Lipids. Hyperphagia. Weight Gain. Rats.
\end{abstract}

\section{RESUMO}

OBJETIVO: Analisar modificações fisiológicas e metabólicas em ratos submetidos à dieta hiperlipídica por um mês.

MÉTODOS: Os animais receberam a dieta AIN-93 modificada, com aumento do teor de lipídeos e diminuição do teor de carboidratos, enquanto o grupo controle recebeu a dieta AIN-93.

RESULTADOS: Foi observado que a dieta hiperlipídica não induziu o ganho de peso, porém levou a um maior ganho de gordura hepática, em comparação ao grupo controle. Os parâmetros bioquímicos, glicemia, colesterol total e proteína sérica não diferiram entre os grupos. Ao mesmo tempo os ratos alimentados com dieta hiperlipídica, apresentaram uma menor ingestão de alimentos.

CONCLUSÃO: O desenvolvimento da obesidade com a dieta hiperlipídica está associado com aumento da ingestão de energia e tempo de exposição à dieta, enquanto a síndrome metabólica está mais associada a dietas com alto teor de gordura e carboidratos, concomitantemente.

Descritores: Obesidade. Lipídeos. Hiperfagia. Ganho de peso. Ratos. 


\section{Introduction}

The prevalence of obesity has been increasing all over the world. This increase is frequently attributed to changes in the life style of western societies, particularly important among them the consumption of high-fat diets ${ }^{1,2}$. Fat is the dietary nutrient with the greatest energy density since it provides $9 \mathrm{kcal}$ per gram, while carbohydrate and protein provide only $4 \mathrm{kcal}$. Thus, and increased fat intake can promote a high energy consumption ${ }^{1,3}$ and for this reason dietary fat is considered to be one of the environmental factors that most contribute to the current epidemic of obesity ${ }^{4,5}$. While the consumption of a high-fat diet is only a hypothesis for the cause of obesity, genetic factors also play an important role $\mathrm{e}^{6,7}$.

Obesity predisposes to a variety of metabolic diseases, most of the times leading to the development of metabolic syndrome, which can be characterized by a groups of metabolic risk factors such as central obesity, insulin resistance, increase arterial pressure, and non-alcoholic steatohepatitis $(\mathrm{NASH})^{8-10}$. In addition, metabolic syndrome increases the risk to develop type 2 diabetes and cardiovascular diseases ${ }^{11}$. Epidemiological studies have documented that nutritional factors such as a high consumption of saturated fat and cholesterol can influence the prevalence of metabolic syndrome ${ }^{12}$.

Studies on animals have indicated that a high-fat (HF) diet is an important component of the etiology of obesity. According to West e York ${ }^{13}$, HF diets lead to excess body fat in monkeys, dogs, swine, squirrels, hamsters, and rats. The mechanisms responsible for the correlation between dietary and body fat are unclear. Hyperphagia may be an important mechanism, although high energy density, palatability and other metabolic effects may also contribute to this correlation ${ }^{14,15}$. According to Hill et al. ${ }^{16}$, HF diets containing $30 \%$ or more of total energy from fats cause obesity in rats, mice, dogs and primates as a result of increased energy intake and efficient energy storage. In contrast, obesity is rare in animals receiving a control fat diet but steatosis can occur in rats receiving a low-protein $\operatorname{diet}^{17}$.

The objective of the present study was to analyze the physiological and metabolic changes resulting from the administration of HF diet to rats.

\section{Methods}

The study was conducted on 14 male Wistar rats aged on average 21 days and with initial mean weight of $59 \mathrm{~g}$, provided by the Central Animal Facilities of Faculty of Medicine of Ribeirão Preto (FMRP-USP). The animals were housed in individual cages on a 12 hour light/dark cycle under controlled temperature, with free access to water and diet. All procedures were approved by the Ethics Committee for Animal Experimentation of FMRP/USP.

The animals were divided into two groups: control group consisting of 7 rats fed the AIN-93 diet containing $4.17 \mathrm{kcal} / \mathrm{g}$ ready diet, and the group high-fat $(\mathrm{HF}+)$ consisting of 7 rats fed a modified AIN-93 ${ }^{18}$ diet with an increased lipid content and a reduced carbohydrate content, containing $6.57 \mathrm{kcal} / \mathrm{g}$. The groups received the respective diets for one month. The composition of the control and HF diets is given in Table 1.

TABLE 1 - Composition of the diets ( $\mathrm{g} / \mathrm{kg}$ total) administered to control animals (AIN-93) and to test animals (HF+)

\section{Nutrients Control (AIN-93) High fat (HF+)}

\begin{tabular}{ccc}
\hline Carbohydrates (q.s.p) & 635 & 155 \\
Protein & 200 & 200 \\
Lipids & 70 & $550 *$ \\
Fibers & 50 & 50 \\
Vitamin mix & 10 & 10 \\
Mineral mix & 35 & 35 \\
Choline & 2,5 & 2,5 \\
Energy value $(\mathrm{kcal} / \mathrm{kg})$ & 4170 & 6570 \\
\hline
\end{tabular}

*350g animal fat and $200 \mathrm{~g}$ soy oil

The amount of diet ingested by the rats was determined by regular weekly weighing of the troughs and of the animals. At the end of 30 days, the two groups were sacrificed by decapitation and blood samples were collected for the determination of total serum cholesterol, serum protein and glycemia. The liver was then weighed and placed in liquid nitrogen $\left(-196^{\circ} \mathrm{C}\right)$ for later determination of hepatic fat by by Bligh and Dyer extraction ${ }^{19}$.

Glycemia, total cholesterol and protein were determined by a colorimetric enzymatic method using a commercial kit (Labtest ${ }^{\circledR}$, Minas Gerais, Brasil). Data were analyzed statistically by the unpaired $t$-test corrected by the Welch test. The level of significance was set at $p<0.05$ for all analyses.

\section{Results}

Regarding the weight evolution of the animals, no significant difference in mean weekly weight variation was observed between groups (Figure 1). However, there was a statistically significant difference in mean weekly diet consumption between groups $(p<0.05)$, with the control group ingesting more ration than the $\mathrm{HF}+$ group throughout the four weeks of the study (Figure 2). In the last week of the study, control animals ingested a mean amount of ration of $114.6 \pm 21.6 \mathrm{~g}$, corresponding to $478 \mathrm{kcal}$, as opposed to $73.4 \pm 13.14 \mathrm{~g}$ for the HF+ group, corresponding to $482 \mathrm{kcal}$. Thus, even though the diets offered to the two groups differed in energy density, the difference in diet consumption resulted in equal calorie intake. 


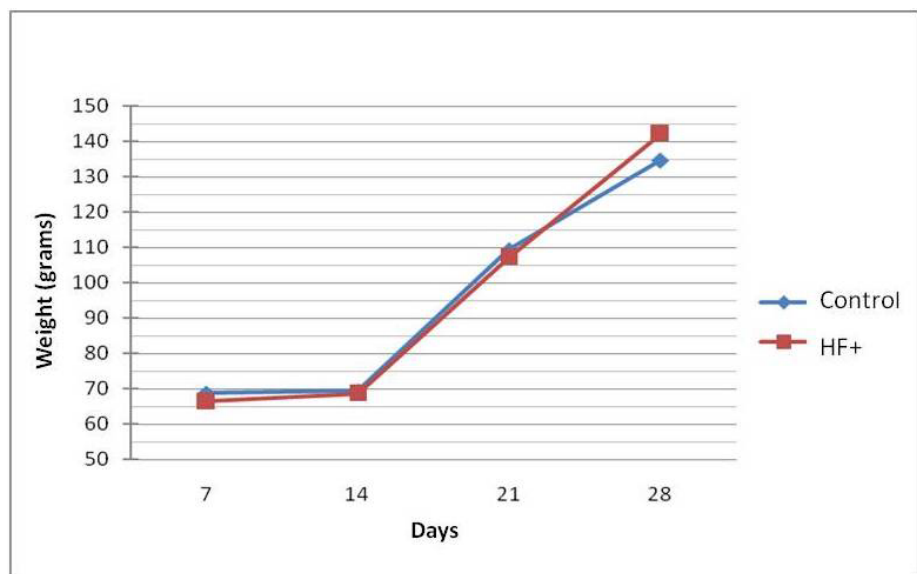

FIGURE 1 - Mean variation of weekly weight in the Control and High-fat $(\mathrm{HF}+)$ groups

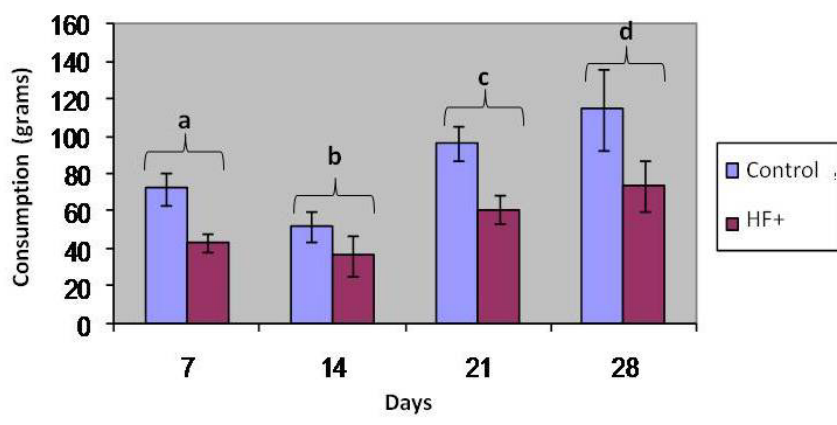

FIGURE 2 - Comparison of mean weekly diet consumption by the Control and High-fat ( $\mathrm{HF}+$ ) groups

a: $p<0.05$ for the groups in the first week,

b: $p<0.05$ for the groups in the second week,

c: $p<0.05$ for the groups in the third week,

$\mathrm{d}: p<0.05$ for the groups in the fourth week

Diet consumption and body weight data clearly show that the first two weeks are a period of animal adaptation to the diet, both the AIN-93 and the HF diet, since the animals reduced their diet intake and did not gain weight. The animals of both groups adapted to their diet starting by the third week, increasing their consumption and starting to gain weight.

The HF+ group presented a significantly higher $(\mathrm{p}<0.002)$ mean value of hepatic fat $(55.2 \% \pm 9.7)$ than the control group $(26.9 \% \pm 11.2)$ (Figure 3$)$. Also, the HF+ group presented higher mean glycemia and serum protein, but the difference from control was nonsignificant. Total cholesterol values also did not differ between groups (Table 2).

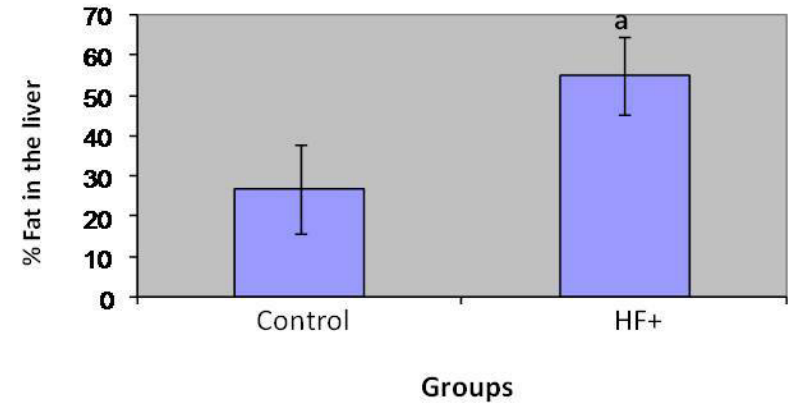

FIGURE 3 - Comparison of mean hepatic fat in the two groups $\mathrm{HF}+=$ high-fat group

a: $p<0.002$ compared to control group.

TABLE 2 - Glycemia, serum protein and total cholesterol values for the two groups. Data are reported as means $\pm \mathrm{SD}$

\begin{tabular}{lccc}
\hline & Controle & HF + & $\boldsymbol{p}$ valor \\
\hline Glycemia $(\mathrm{mg} / \mathrm{dl})$ & $95.46 \pm 20.02$ & $120.3 \pm 39.32$ & $p>0.05$ \\
Serum protein $(\mathrm{g} / \mathrm{dl})$ & $4.97 \pm 0.38$ & $5.07 \pm 1.41$ & $p>0.05$ \\
Total cholesterol $(\mathrm{mg} / \mathrm{dl})$ & $116.12 \pm 19.96$ & $79.04 \pm 27.94$ & $p>0.05$
\end{tabular}

\section{Discussion}

In the present study, the rats that consumed the high-fat (HF) diet ingested a smaller amount of food than the controls, in contrast to the hypothesis that diets with a high fat content promote hyperphagia in rodents ${ }^{20}$. However, since the energy density of the HF diet was higher than the energy density of the control diet, i.e., $6.57 \mathrm{kcal} / \mathrm{g}$ versus $4.17 \mathrm{kcal} / \mathrm{g}$, both groups consumed the same amount of calories. The present data agree with those reported by Chen et al. ${ }^{21}$, who also observed a reduced food consumption in animals receiving an $\mathrm{HF}+$ diet compared to control.

Both the rats receiving the AIN-93 diet and the HF diet presented a discrete weight gain during the first two weeks, with a more marked weight gain starting in the third week, with no significant difference between. Also, Akagiri Akagiri et al. ${ }^{22}$, in a 14 week study, did not detect significant differences in weight gain between animals fed the HF diet and controls, although the first one tended to gain more weight. In contrast, Chen et $a l .^{21}$, after six weeks of study, observed that rats receiving a high-calorie HF diet (22.4\% more energy than the control diet) gained more weight than rats receiving a normal diet. The same result was obtained by Matsuzawa-Nagataa et $a l .^{23}$, after 24 weeks of administration of the HF diet. 
Buettner et $a l .{ }^{24}$ observed that prolonged offer of a lipid-rich diet induces weight gain in susceptible rats of the order of 10 and $20 \%$ compared to control. According to these authors, the induction of obesity is more effective when the high-fat diet is started at a young age and is continued for several weeks. The weight gain is gradual, increasing discretely during the first two weeks and becoming more marked after the fourth week, corroborating the data presented in this study. However, some authors have suggested that rats fed an HF diet maintain metabolic homeostasis for approximately six weeks, when they start to develop obesity and insulin resistance

A possible explanation for the influence of time of exposure to the HF diet on weight gain is that diet induces a positive fat balance on a short-term basis due to the loss of adjustment between fat oxidation and consumption. In the long term, this positive accumulation can lead to weight gain ${ }^{1}$ and therefore, the longer the duration of the diet, the greater the gain of body weight and $\mathrm{fat}^{13}$. However, there is controversy about the definition of a long term.

Another variable that may influence the weight gain of the animals is the type of lipid used in the formulation of high-fat diet. In human studies there are the influence of type of fat and other factors, as exercise ${ }^{25}$. In a prospective study, Colditz et al. ${ }^{26}$ observed that weight gain showed a slight positive association with animal fat (usually seen as harmful) and negative association with vegetable fat (usually seen as beneficial). On this basis, even though the difference may be small, these two types of fat may be metabolically different in terms of their effect on weight gain ${ }^{3}$.

Literature data show that the fat content of the diet influences the amount of body fat only when the energy consumption is also increased ${ }^{27}$. In a study of two groups of rats receiving an $\mathrm{HF}$ diet and a low-fat (LF) diet, both isocaloric, it was observed that the weight gain of the animals of the two groups was similar, but that visceral fat and adipose tissue were significantly increased in the first one. In contrast a high-calorie HF diet led to greater weight gain than in the two groups cited above $^{28}$, in agreement with the findings of the present study showing that a high-fat content, but with an isocaloric content compared to the control diet, did not induce weight gain.

It has been suggested that energy density, rather than a simple increase in the percent fat of the diet is the actual factor predisposing to weight gain in many animal studies ${ }^{28}$. Since high-fat diets are characterized by increased energy density and palatability, they frequently lead to higher energy intake. Thus, the HF diet is expected to be able to increase body weight ${ }^{29-31}$.

There is much controversy about the weight gain of rats fed an HF diet and a possible explanation for this wide variety of results could be the absence of standardization of the HF diets used in the various studies. Many of these studies do not describe the exact quantity of lipids of the HF diet, its energy density (hypercaloric or isocaloric), the time of exposure to the diet, or the types of fat used (animal or vegetable fat) ${ }^{24}$.

The groups did not differ significantly regarding the other biochemical parameters such as glycemia, total cholesterol and serum protein. Akagiri et al. ${ }^{22}$, also did not detect significant differences in glycemia between groups and concluded that, even though there were no significant differences between groups regarding various parameters, many characteristics of metabolic syndrome, including the accumulation of visceral adipose tissue and the reduced expression of adinopectin, occurred earlier in the $\mathrm{HF}+$ group. In contrast, Xie et al..$^{32}$ demonstrated that rats fed an $\mathrm{HF}$ diet had a discrete increase in fasting glycemia and a significant increase in serum cholesterol compared to control, with no significant increase in hepatic fat levels. In another study, no changes in metabolic parameters occurred in rats receiving an $\mathrm{HF}$ diet for six weeks compared to control. In contrast, after 24 weeks $\mathrm{HF}+$ rats had a greater quantity of visceral fat and accumulation of fatty acids in the liver. The authors also observed impaired glucose tolerance and insulin resistance ${ }^{29}$.

According to Buettner et $a l .^{24}$, the HF diet may induce hepatic steatosis and signs of hepatic insulin resistance in the animals, as also observed in obese humans. These authors believe that the mechanism by which the diet induces fat deposition and $\mathrm{NASH}$ in rats could be the activation of hepatic inflammatory cycles.

There is discrepancy in the literature about the effects of the HF diet on glycemia. However, Buettner et al. ${ }^{24}$, on the basis of a literature review, concluded that the prolonged consumption (a minimum of 2 weeks) of HF diets will eventually lead to hyperglycemia in most rats. According to these authors, the type of fat used in an HF diet does not influence the development of insulin resistance, even though some poorly conducted studies have reported this relation.

Shiraev et al. ${ }^{33}$ offered three types of diet to Sprague-Dawley rats: control (14\% lipids), ad libitum HF (35\% lipids) and HF isocaloric to the control diet, for 11 weeks and observed increased body fat, glucose intolerance and elevation of serum insulin in the groups receiving the HF diet. The authors concluded that the presence of large amounts of fat in the diet, even with low calorie content, can cause an increase in adiposity and hyperlipidemia, which may lead to insulin resistance on a long-term basis.

To elaborate an HF diet, part of one of two macronutrients (carbohydrate and protein) must be replaced with fat. The change in the equilibrium of these macronutrients can have different metabolic effects. In a 10 week study on rats, the food intake of three groups was compared: control group receiving a low-fat diet (CG) and two $\mathrm{HF}+$ groups, one of them receiving a high carbohydrate diet (HC) and the other a low carbohydrate diet (LC). The body weight of rats fed the HC diet was greater due to their greater increase in body weight and greater food consumption. Postprandial glycemia was higher in the HC group than in the LC group $^{2}$. According to this investigator, the combination of a diet rich in fat and carbohydrate is responsible for the development of some peculiarities related to metabolic syndrome in rats.

In contrast, low-carbohydrate and high-fat and protein diets have attracted attention in the treatment of obesity in humans ${ }^{34,35}$, with the reduction of weight being mainly attributed to the reduced energy consumption possibly caused by the greater ability of protein to satiate ${ }^{35}$ and also to the increase thermogenesis induced by the high protein content of the $\operatorname{diet}^{36}$. 


\section{Conclusions}

Rats fed an HF diet did not show a greater weight gain because they ingested smaller amounts of this diet compared to rats fed the control diet, so that both diets provided the same quantity of energy to both groups. The reduction of the amount of carbohydrates in the diet in order to increase the amount of lipids may explain the smaller dietary consumption of the HF diet. However, this increase in fat content of the diet can lead to an increase in the risk factors for metabolic syndrome, including an increase in hepatic fat and a tendency to higher glycemia values. In man, a prolonged time of exposure to an HF diet may lead to an increased formation of atheroma plaques since dietary fat first reaches the circulation before accumulating in the liver.

An increased energy intake is needed for an HF diet to induce obesity since the development of obesity is characterized by an imbalance between energy consumption and calorie expenditure. The time of exposure to this diet is also responsible for weight gain and for the development of some characteristics related to metabolic syndrome. In fact this syndrome is more associated with diets with simultaneously increased lipid and carbohydrate that favor an increase in adipose tissue, but not in body weight, which in the long term may lead to the development of insulin resistance.

High-fat diets normally promote an increased calorie intake since they are more palatable and contain high energy density. For this reason, high-fat diets should be avoided since their long-term use can result in weight gain, increased adipose tissue, glucose intolerance, elevation of circulating serum lipids, and hepatic steatosis.

\section{References}

1. Schrauwen P, Westerterp KR. The role of high-fat diets and physical activity in the regulation of body Weight. Br J Nutr. 2000;84:417-27.

2. Klaus S. Increasing the Protein: Carbohydrate Ratio in a high-fat diet delays the development of adiposity and improves glucose homeostasis in Mice1. J Nutr. 2005;135:1854-8.

3. Willett WC. Is dietary fat a major determinant of body fat? Am J Clin Nutr. 1998;67:556-62.

4. Peters JC. Dietary fat and body weight control. Lipids. 2003;38:123-7.

5. Bray GA, Paeratakul S, Popkin BM. Dietary fat and obesity: a review of animal, clinical and epidemiological studies. Physiol Behav. 2004;83:549-55.

6. Bouchard C, Tremblay A. Genetic influences on the response of body fat and fat distribution to positive and negative energy balances in human identical twins. J Nutr. 1997;127:943-7.

7. Fitzgerald SM, Brands MW, Henegar LK, Hall JE. Cardiovascular and renal responses to a high fat diet in Osborne Mendel rats. Am J Physiol Regul Integr Comp Physiol. 2001;281:547-52.

8. Shaw DI, Hall WL, Williams CM. Metabolic syndrome: what is it and what are the implications? Proc Nutr Soc. 2005;64:349-57.

9. Shibata G, Tsuchiya H. Pathophysiology of NASH: insulin resistance, free fatty acids and oxidative stress. J Clin Biochem Nutr. 2006;38:127-32. 10. Watanabe S, Hojo M, Nagahara A. Metabolic syndrome and gastrointestinal diseases. J Gastroenterol. 2007;42:267-74.

11. Rutter MK, Meigs JB, Wilson PW. Cardiovascular risk and the metabolic syndrome. Metab Syndr Relat Disord. 2006;4:252-60.
12. Esposito K, Ceriello A, Giugliano D. Diet and the metabolic syndrome. Metab Syndr Relat Disord. 2007;5:291-6.

13. West DB, York B. Dietary fat, genetic predisposition, and obesity: lessons from animal models. Am J Clin Nutr. 1998;67:505-12.

14. Stubbs RJ, Harbron CG, Murgatroyd PR, Prentice AM. Covert manipulation of dietary fat and energy density: effect on substrate flux and food intake in men eating ad libitum. Am J Clin Nutr. 1995;62:316-29.

15. Schiffman SS, Graham BG, Sattely-Miller EA, Warwick ZS. Orosensory perception of dietary fat. Curr Dir Psychol Sci. 1998;7:137-43. 16. Hill JO, Melanson EL, Wyatt HT. Dietary fat intake and regulation of energy balance: implications for obesity. J Nutr. 2000;130:284-8.

17. Castro, Gabriela S. F; Mialich, Mirele S; Anjos, Eloisa M; Almeida, Lillian P; Arroyo, Paula F; Portari, Guilherme V; Jordão Junior, Alceu A. Caracterização da esteatose hepática não alcoólica induzida por dieta hipoprotéica em ratos. Medicina (Ribeirão Preto). 2009;42;48-53.

18. Reeves PG, Nielsen FH, Fahey GC JR. AIN-93 purified diets for laboratory rodents: final report of the American Institute of Nutrition ad hoc writing committee on the reformulation of the AIN-76A rodent diet. J Nutr. 1993;123:1939-51.

19. Leonardi DS, Feres MB, Portari GV, Zanuto ME, Zucoloto S, Jordão AA. Low-carbohydrate and high-fat diets on the promotion of hepatic steatosis in rats. Exp Clin Endocrinol Diabetes. 2010;118;724-9

20. Ramirez I. Does dietary hyperphagia contradict the lipostatic theory? Neurosci Biobehav Rev. 1990;14:117-23.

21. Chen WP, Ho BY, Lee CL, Lee CH, Pan TM. Red mold rice prevents the development of obesity, dyslipidemia and hyperinsulinemia induced by high-fat diet. Int J Obes. 2008;32:1694-704.

22. Akagiri S, Naito Y, Ichikawa H, Mizushima K, Takagi T, Handa O. A mouse model of metabolic syndrome; increase in visceral adipose tissue precedes the development of fatty liver and insulin resistance in high-fat diet-fed male KK/Ta mice. J Clin Biochem Nutr. 2008;42:150-7.

23. Matsuzawa-Nagataa N, Takamura T, Ando H, Nakamuraa S, Kurita $\mathrm{S}$, Misu $\mathrm{H}$. Increased oxidative stress precedes the onset of high-fat diet-induced insulin resistance and obesity. Metabolism. 2008;57:1071-7.

24. Buettner R, Scholmerich J, Bollheimer LC. High-fat diets: modeling the metabolic disorders of human obesity in rodents. Obesity. 2007; 15:798-808

25. Klesges RC, Klesges LM, Haddock CK, Eck LH. A longitudinal analysis of the impact of dietary intake and physical activity on weight change in adults. Am J Clin Nutr. 1992;55:818-22.

26. Colditz GA, Willett WC, Stampfer MJ, London SJ, Segal MR, Speizer FE. Patterns of weight change and their relation to diet in a cohort of healthy women. Am J Clin Nutr. 1990;51:1100-5.

27. Westerterp KR, Verboeket-Van de Venne WPHG, Westerterp-Plantenga MS, Velthuis-Te Wierik EJM, Graaf CD, Weststrate JA. Dietary fat and body fat: an intervention study. Int J Obes Relat Metab Disord. 1996;20:1022-6.

28. Woods SC, Seeley RJ, Rushing PA, D'alessio D, Tso P. A Controlled high-fat diet induces an obese syndrome in rats. J Nutr. 2003;133:1081-7. 29. Miller WC, Lindeman AK, Wallace J, Niederpruem M. Diet composition, energy intake, and exercise in relation to body fat in men and women. Am J Clin Nutr. 1990;52:426-30.

30. Prewitt TE, Schmeisser D, Bowen PE, Aye P, Dolecek TA, Langenberg P. Changes in body weight, body composition, and energy intake in women fed high and low-fat diets. Am J Clin Nutr. 1991;54:304-10.

31. Verboeket-Van de Venne WPHG, Westerterp KR, Herman Limpens TJEMB, Graf CD, Hof KVH, Weststrate JA. Long-term effects of consumption of full-fat or reduced-fat products in healthy non-obese volunteers: assessment of energy expenditure and substrate oxidation. Metabolism. 1996;45:1004-10. 
32. Xie W, Zhang Y, Wang N, Zhou H, Du L, Ma X. Novel effects of macrostemonoside A, a compound from Allium macrostemon Bung, on hyperglycemia, hyperlipidemia, and visceral obesity in high-fat diet-fed C57BL/6 mice. Eur J Pharmacol. 2008;599:159-65.

33. Shiraev T, Chen H, Morris MJ. Differential effects of restricted versus unlimited high-fat feeding in rats on fat mass, plasma hormones and brain appetite regulators. J Neuroendocrinol. 2009;21:602-9.
34. Acheson KJ. Carbohydrate and weight control: where do we stand? Curr Opin Clin Nutr Metab Care. 2004;7:485-92.

35. Astrup A, Meinert-Larsen T, Harper A. Atkins and other low-carbohydrate diets: hoax or an effective tool for weight loss? Lancet. 2004;364:897-9.

36. Westerterp KR. Diet induced thermogenesis. Nutr Metab. 2004;1:1-5.

\section{Correspondence:}

Andresa Marques de Matos

Rua Lamartine Belém Barbosa, 980

14096-250 Ribeirão Preto - SP Brasil

andresa.mattos@usp.br

andresa_nutrição@yahoo.com.br

Conflict of interest: none

Financial source: none

${ }^{1}$ Research performed at Laboratory of Nutrition and Metabolism, Faculty of Medicine of Ribeirao Preto, University of Sao Paulo (FMRP-USP), Ribeirao Preto-SP, Brazil.

Presented at the XII National Congress on Experimental Surgery of the Brazilian Society for Development of Research in Surgery-SOBRADPEC, 2011 October 26-29 Ribeirao Preto-SP, Brazil. 